\title{
PENGARUH MODEL PEMBELAJARAN ADVANCE ORGANIZER BERBANTUAN PETA KONSEP TERHADAP HASIL BELAJAR FISIKA SISWA SMA NEGERI 1 LINGSAR
}

\author{
Raeha Nopiani, Ahmad Harjono, Hikmawati. \\ Program Studi Pendidikan Fisika \\ Universitas Mataram \\ Jalan Majapahit No. 62, Mataram \\ E-Mail: raehanopianiyakub@gmail.com
}

\begin{abstract}
This study aims to determine the effect of advanced organizer learning model using concept mapping on student's physics learning achievement SMA Negeri 1 Lingsar. This research type is quasi experiment with pretest-posttest control group design. The population of this study is all students of class XI IPA SMA Negeri 1 Lingsar with sampling technique using purposive sampling. The classes that sampled are class XI IPA 2 as experiment class and class XI IPA 1 as control class. The results of study are learning outcome in the cognitive aspect while affective and psychomotor aspect as supporting data. The instrument was used to measure the learning outcome of the cognitive aspect is an objective test. The result of prerequisite analysis test shows that posttest data are normal and homogeneous distributed so that statistic test used is parametric statistic t-test poled varian with $t$ test criteria of two parties, and obtained $t_{\text {result }}=2.19$ and $t_{\text {table }}=1.99$ at $5 \%$ significant level. Therefore $t_{\text {result }}>t_{\text {table }}$ then $H_{o}$ is rejected and $H_{a}$ is accepted, it can be concluded that there is the effect of advanced organizer learning model using concept mapping on student's physics learning achievement SMA Negeri 1 Lingsar.
\end{abstract}

Keywords: Advance organizer, concept map, learning outcomes.

\section{PENDAHULUAN}

Pendidikan pada dasarnya merupakan usaha pengembangan sumber daya manusia (SDM) melalui kegiatan pengajaran (Sinulangga \& Munte, 2012). Selain itu menurut Hamalik dalam (Fadila, et.al., 2015) pendidikan adalah suatu proses dalam rangka mempengaruhi siswa agar dapat menyesuaikan diri sebaik mungkin terhadap lingkungannya, sehingga akan menimbulkan perubahan dalam dirinya yang memungkinkannya untuk berfungsi secara kuat dalam kehidupan masyarakat. Pendidikan diharapkan memberikan mutu yang baik sehingga tujuan pendidikan dapat tercapai dan diterapkan dengan baik. Menurut Widodo \& Widayanti (2013) dalam sistem pendidikan nasional rumusan tujuan pendidikan mengacu pada klasifikasi hasil belajar dari Bloom yang secara garis besar yaitu aspek kognitif, aspek afektif, dan aspek psikomotor. Pada tingkatan yang lebih praktis, taksonomi ini telah banyak membantu praktisi pendidikan untuk merumuskan tujuan-tujuan belajar dalam bahasa yang mudah dipahami, operasional, serta dapat diukur (Pahriah, 2016). Pendidikan yang diberikan di sekolah meliputi beberapa ilmu pengetahuan salah satunya adalah fisika.

Fisika sebagai salah satu cabang dari IPA yang mempelajari gejala-gejala alam dan peristiwa alam baik yang dapat dilihat maupun yang bersifat abstrak (Nurqomariah, et.al., 2015). Pembelajaran fisika yang efektif dan efisien dapat diciptakan, salah satunya dengan menggunakan metode atau model pembelajaran yang bervariasi (Susanti, et.al., 2016). Pembelajaran fisika bertujuan untuk mengembangkan daya nalar siswa dan siswa mampu memecahkan masalah fisika yang berkaitan dengan kehidupan sehari-hari. Selain itu, pembelajaran fisika memiliki tujuan yang sebagaimana mestinya tersirat dalam Kurikulum Tingkat Satuan Pendidikan (KTSP), yaitu pembelajaran yang membekali siswa dengan pengetahuan, pemahaman dan sejumlah kemampuan untuk mengembangkan ilmu 
pengetahuan dan teknologi. Tujuan tersebut dapat tercapai dengan pembelajaran fisika disekolah harus menekankan pada pemahaman konsep fisika yang berlandaskan hakikat IPA yang mencakup produk, proses dan sikap ilmiah.

Berdasarkan tujuan pembelajaran fisika, maka kemampuan memahami konsep fisika merupakan salah satu kemampuan yang penting dan harus dimiliki siswa. Namun, disisi lain pelajaran fisika merupakan mata pelajaran yang kurang disukai siswa. Kesulitan siswa untuk memahami konsep yang diajarkan dipengaruhi oleh beberapa faktor antara lain: materi, guru, dan latar belakang siswa itu sendiri. Selain itu, guru mengajar dengan menggunakan model pengajaran langsung atau berpusat pada guru seharusnya paradigma pembelajaran yang berpusat pada guru hendaknya diubah menjadi pembelajaran yang berpusat pada siswa. Materi yang diajarkanpun bersifat mengacu pada buku, tidak mengacu pada masalah kontekstual yang dekat dengan kehidupan sehari-hari siswa sehingga pembelajaran fisika menjadi kurang bermakna dan menyenangkan. Faktor yang berasal dari latar belakang siswa sendiri adalah bahan pelajaran, ketekunan, keuletan, kerajinan, dan kedisiplinan dalam belajar (Aziz, et.al., 2015). Selain itu, pengajaran yang efektif disusun dari serangkaian sarana tentang caracara untuk menjangkau para siswa dan membantu mereka membangun reservoar pengetahuan, keterampilan, dan nilai-nilai yang abadi (Joyce, et.al., 2016).

Menurut Ausubel dalam Dahar (2011) berbunyi "The most important single factor influencing learning is what the learner already knows. Ascertain this and teach him accordingly". Pernyataan Ausubel inilah yang menjadi inti teori belajarnya. Jadi, terjadinya pembelajaran yang bermakna, konsep baru harus dikaitkan dengan struktur kognitif siswa yang telah ada.

Berdasarkan permasalahan di atas salah satu upaya yang dilakukan untuk meningkatkan hasil belajar dalam belajar fisika diperlukan cara membuat siswa menjadi lebih aktif dalam proses belajar. Model pembelajaran advance organizer ini dapat ditingkatkannya aspek pemahaman konsep yang akan membantu hasil belajar fisika siswa meningkat. Menurut Rahayu, et.al., (2010) bahwa advance organizer adalah suatu rencana pembelajaran yang digunakan untuk menguatkan struktur kognitif siswa ketika mempelajari konsepkonsep atau informasi yang baru dan bagaimana sebaiknya pengetahuan itu disusun serta dipahami dengan benar. Selain itu, diperkuat oleh Oloyede (2011) terhadap 138 siswa SMA melaporkan bahwa advance organizer meningkatkan retensi pembelajaran kimia mereka.

Proses siswa dalam menghubungkan antar konsep yang telah diketahuinya dapat terlihat ketika menggambarkannya dalam peta konsep, karena model pembelajaran advance organizer berhubungan erat dengan peta konsep. Jika siswa mampu menghubungkan informasi awal yang telah diketahui sebelumnya dengan pengetahuan yang baru, maka itulah yang dikatakan sebagai pengetahuan yang bermakna. Menurut Dahar (2011) kebermaknaan belajar adalah pembelajaran yang berhubungan atau mengkaitkan informasi itu pada pengetahuan yang dimilikinya. Peta konsep inilah yang akan membantu siswa mengetahui pengorganisasian konsep-konsep fisika. Menurut Rahim dalam (Aziz \& Jair, 2009) tentang penggunaan peta konsep yang dilihat dapat memudahkan pemikiran pelajar, membantu mengkukuhkan daya ingatan dan pelajar dapat mengingati fakta-fakta penting yang kemudiannya boleh diuraikan dengan baik.

Peneliti berharap penggunaan model pembelajaran advance organizer berbantuan peta konsep mampu meningkatkan hasil belajar siswa pada pembelajaran fisika. Menurut Nurhayati \& Subroto (2012) bahwa masih rendahnya hasil belajar kimia menunujukkan bahwa mahasiswa mengalami kesulitan dalam mempelajari konsep-konsep kimia. Konsepkonsep fisika terkadang bersifat abstrak dan kurangnya variasi yang digunakan guru dalam proses pembelajaran. Hasil observasi di SMA Negeri 1 Lingsar kelas XI IPA yang menunjukkan proses pembelajaran yang masih konvensional dan suasana kelas yang cenderung tidak interaktif. 


\section{METODE PENELITIAN}

Penelitian kuasi eksperimen ini menggunakan pretest-posttest control group design. Penelitian ini melibatkan variabel bebas, yaitu model pembelajaran advance organizer berbantuan peta konsep dan variabel terikat yaitu hasil belajar, serta variabel kontrol yaitu guru, yang mengajar, waktu dan bahan ajar. Penelitian ini dilakukan di SMA Negeri 1 Lingsar. Sampel dipilih secara purposive sampling. Sampel penelitian terdiri dari dua kelas yaitu 35 siswa sebagai kelas kontrol dan 33 siswa sebagai kelas eksperimen. Instrumen yang digunakan adalah tes untuk ranah kognitif. Teknik pengumpulan data berupa tes tertulis berbentuk soal pilihan ganda sebanyak 30 soal. Instrumen tes kemampuan pemecahan masalah sebelum digunakan harus memenuhi beberapa syarat yaitu uji validitas, reliabilitas, tingkat kesukaran soal dan daya beda. Uji analisis data menggunakan uji-t polled varian dengan taraf signifikan $5 \%$ dan derajat kebebasan $(\mathrm{dk})=\mathrm{n}_{1}$ $+\mathrm{n}_{2}-2$. Data hasil ranah kognitif yang diperoleh dianalisis dengan $\mathrm{N}$-gain untuk mengetahui peningkatan kelas eksperimen dan kelas kontrol.

\section{HASIL DAN PEMBAHASAN}

Penelitian ini bertujuan untuk mengetahui pengaruh model pembelajaran advance organizer berbantuan peta konsep terhadap hasil belajar fisika siswa SMA Negeri 1 Lingsar. Model pembelajaran advance organizer berbantuan peta konsep diterapkan di kelas eksperimen sedangkan model pembelajaran direct instruction diterapkan di kelas kontrol. Instrumen menggunkan 30 soal pilihan ganda yang sudah divalidasi. Data tentang hasil kemampuan siswa sebelum dan sesudah perlakuan diperoleh melalui tes awal dan tes akhir yang ditunjukkan pada Tabel 1.

Tabel 1. Hasil Tes Awal Kelas Eksperimen dan Kelas Kontrol

\begin{tabular}{lcc}
\hline \multirow{2}{*}{ Deskripsi } & \multicolumn{2}{c}{ Kelas } \\
\cline { 2 - 3 } & Eksperimen & Kontrol \\
\hline Jumlah siswa & 33 & 35 \\
Rata-rata & 43,79 & 33,51 \\
Nilai tertinggi & 70 & 60 \\
Nilai terendah & 20 & 17 \\
\hline
\end{tabular}

Berdasarkan Tabel 1. di atas terlihat bahwa nilai rata-rata kelas kontrol dan eksperimen yaitu 43,79 dan 33,51 dengan selisih nilai rata-rata tes awal kedua kelas tersebut adalah 10,28. Sedangkan hasil tes akhir pada kelas eksperimen dan kelas kontrol dapat dilihat pada Tabel 2. sebagai berikut:

Tabel 2. Hasil Tes Akhir Kelas Eksperimen dan Kelas Kontrol

\begin{tabular}{lcc}
\hline \multirow{2}{*}{ Deskripsi } & \multicolumn{2}{c}{ Kelas } \\
\cline { 2 - 3 } & Eksperimen & Kontrol \\
\hline Jumlah siswa & 33 & 35 \\
Rata-rata & 75,00 & 68,91 \\
Nilai tertinggi & 93 & 87 \\
Nilai terendah & 53 & 47 \\
\hline
\end{tabular}

Tabel 2. menunjukkan bahwa rata-rata nilai kelas ekperimen 75,00 dan rata-rata nilai kelas kontrol 68,91, dengan selisih nilai ratarata kedua kelas tersebut adalah 6,09. Kelas eksperimen memiliki nilai tertinggi 93 dan terendah 53 sedangkan kelas kontrol memiliki nilai tertinggi 87 dan terendah 47. Data hasil penelitian tersebut kemudian diolah dan diuji menggunakan $N$-gain. Hasil perhitungan uji $N$ gain siswa dapat dilihat dalam Gambar 2. berikut. 


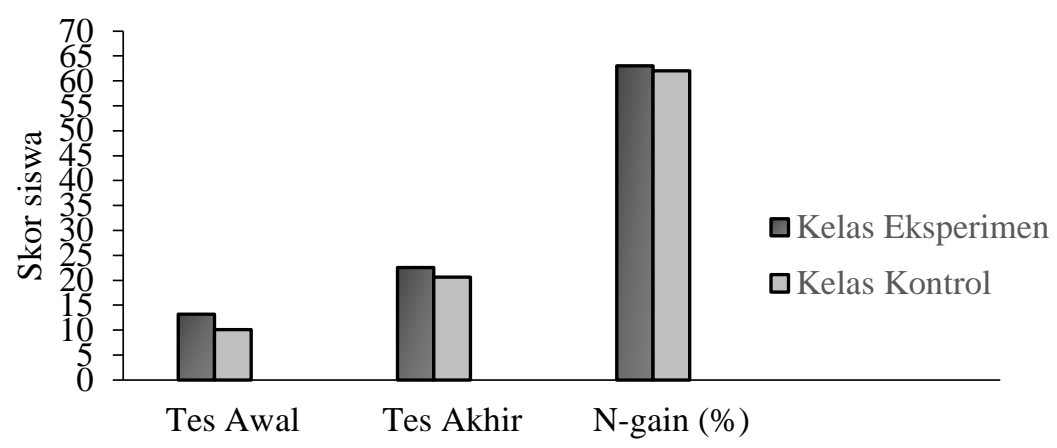

Gambar 1. Uji N-gain Siswa Secara Keseluruhan

Perhitungan skor rata-rata $N$-gain juga dilakukan untuk mengetahui peningkatan pemahama konsep fisika siswa per sub materi. Materi fluida statis pada penelitian ini dibagi menjadi tujuh sub materi yaitu; (1) konsep tekanan, (2) konsep hukum pascal, (3) konsep hukum hidrostatika, (4) hukum archimedes, (5) tegangan permukaan, (6) gejala kapilaritas, (7) viskositas. Hasil perhitungan skor rata-rata $N$ gain per sub materi pada kedua kelas untuk ranah kognitif ditampilkan dalam Gambar 2.

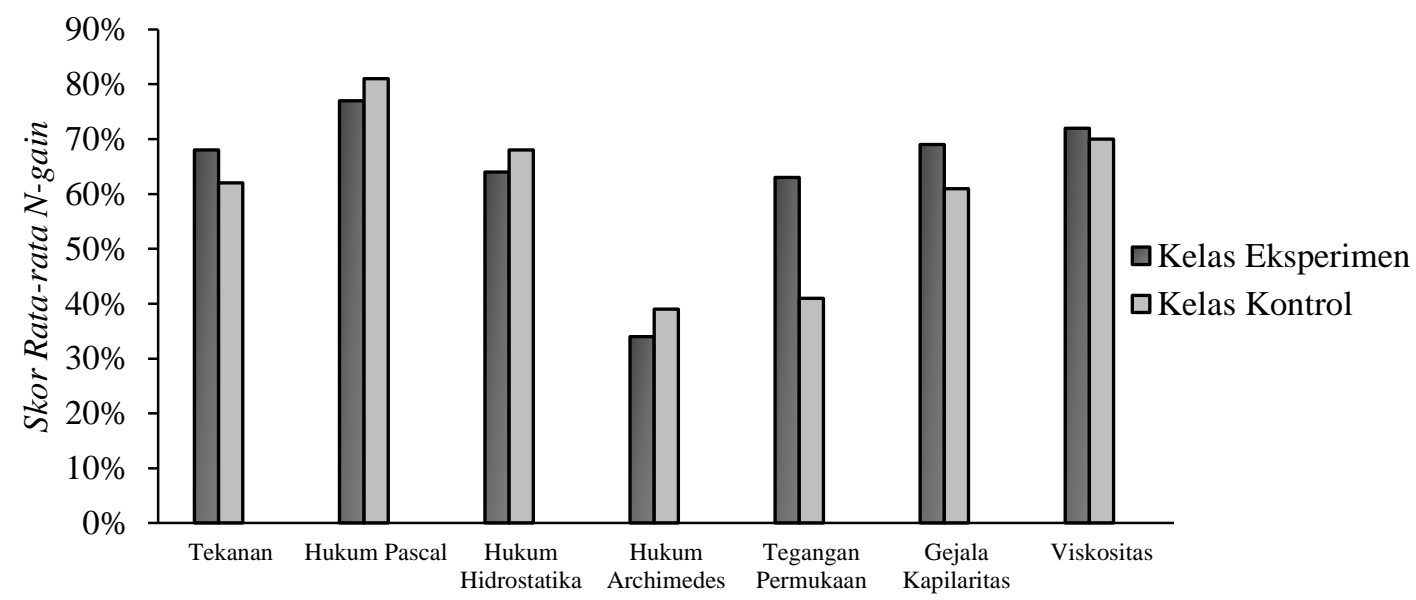

Gambar 2. Perbandingan Skor N-gain Tiap Sub Materi Kedua Kelas Pada Ranah Kognitif

Skor rata-rata $N$-gain pada kelas eksperimen lebih besar dibandingkan kelas kontrol pada sub materi tekanan, tegangan permukaan, gejala kapilaritas, dan viskositas.
Sedangkan sub materi hukum pascal, hukum hidrostatika, dan hukum Archimedes memiliki skor $\mathrm{N}$-gain yang lebih besar di kelas kontrol dibandingkan di kelas ekseperrimen.

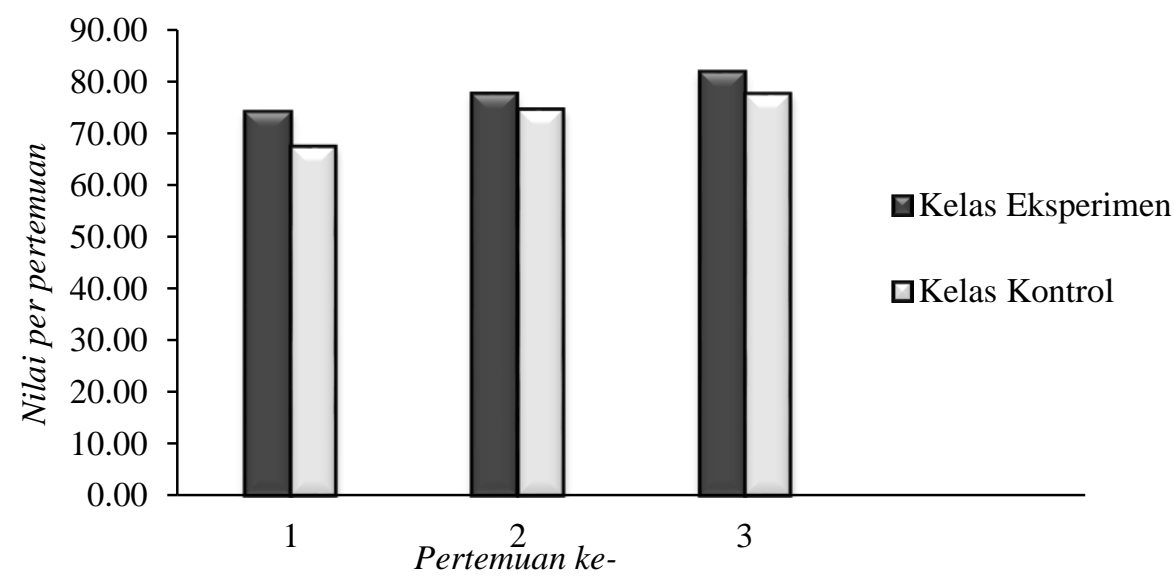


Gambar 3. Perbandingan Hasil Belajar Kedua Kelas pada ranah Afektif

Berdasarkan Gambar 3. diketahui bahwa hasil belajar untuk ranah afektif pada kelas eksperimen memiliki kriteria yang sama setiap pertemuannya. Pada pertemuan pertama ratarata nilai siswa yang termasuk dalam kategori baik dengan rata-rata 74,09 dengan nilai tertinggi 90 dan terendah 60. Pertemuan kedua rata-rata nilai siswa berada pada kategori baik dengan rata-rata 77,58 dengan nilai tertinggi 90 dan terendah 60. Pertemuan ketiga terlihat ratarata nilai siswa yang termasuk kategori sangat baik dengan rata-rata 81,82 dengan nilai tertinggi 90 dan terendah 75 . Hal ini menunjukkan bahwa hasil belajar pada ranah afektif siswa mengalami peningkatan pada setiap pertemuan yang dilihat dari nilai ratarata, kategori, nilai tertinggi dan nilai terendah.

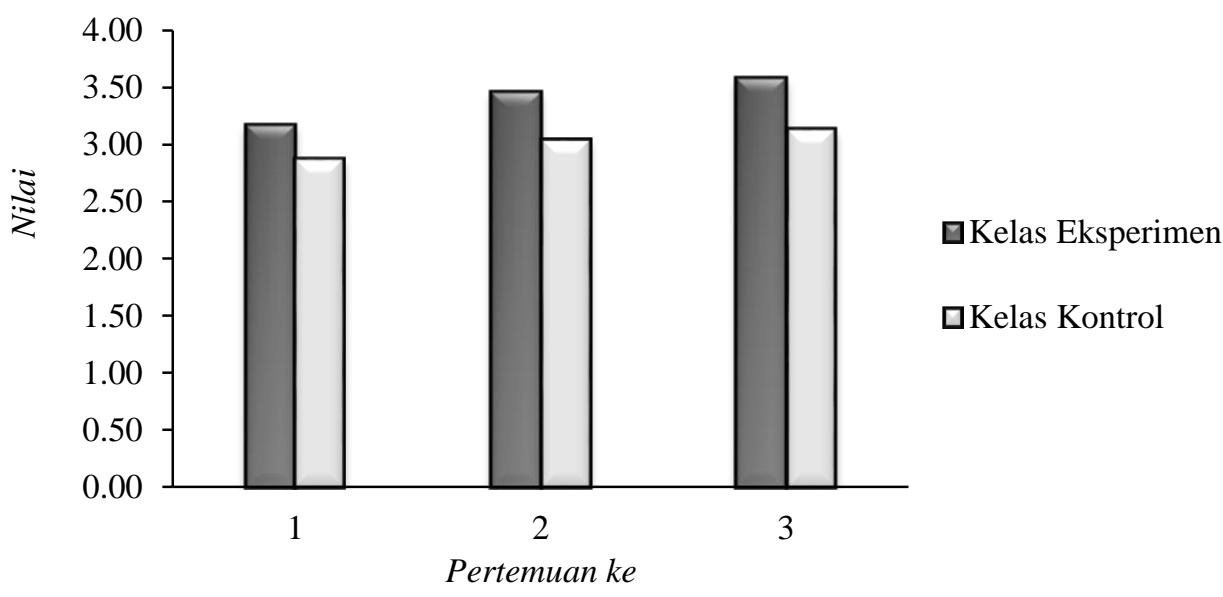

Gambar 4. Perbandingan Hasil Belajar Kedua Kelas pada ranah Psikomotor

Berdasarkan Gambar 4. diketahui kelas eksperimen dan kelas kontrol sama-sama mengalami peningkatan pada ranah psikomotor, karena adanya peningkatan di setiap pertemuan di masing-masing kelas dengan kategori yang tetap.

Data yang dideskripsikan adalah data hasil belajar fisika siswa pada ranah kognitif di analisis berdasarkan hasil tes awal dan tes akhir pada kedua kelompok sampel. Tes awal diberikan sebelum perlakuan dan tes akhir diberikan setelah perlakuan. Berdasarkan uji homogenitas dan uji normalitas dari data tes akhir hasil belajar ranah kognitif menunjukkan bahwa kedua kelas homogen dan terdistribusi normal. Hasil perhitungan uji-t dua sampel diperoleh nilai $t_{\text {hitung }}$ lebih besar dari nilai $t_{\text {tabel }}$ yaitu $2,19>1,99$.

Perbedaan hasil belajar siswa pada ranah kognitif ini dipengaruhi oleh perlakuan yang diberikan dikedua kelas. Kelas eksperimen yang diberikan perlakuan berupa model pembelajaran advance organizer berbantuan peta konsep memperoleh nilai rata-rata yang lebih tinggi dari pada kelas kontrol yang hanya diberikan model pembelajaran langsung (direct instruction). Hal tersebut disebabkan, karena siswa pada kelas eksperimen diberikan peta konsep yang akan membantu pada proses pembelajaran, sehingga lebih mudah memahami dan mengingatnya yang ditunjukkkan dengan kemampuan menjawab benar tes hasil belajar di kelas eksperimen lebih banyak di bandingkan dengan kelas kontrol. Peta konsep memegang peranan penting dalam proses pembelajaran ini dikarenakan siswasiswa terbantu menghubungkan dan mengetahui konsep-konsep baru dengan materi yang sudah dipelajari. Kunci utama memahami konsep-konsep yang sudah diberikan, siswa harus menganalisis informasi yang sudah disediakan pada contoh-contoh. Cara mengetahui siswa-siswa memahami konsepkonsep yang sudah diajarkanpun bisa diketahui 
dengan cara meminta kembali siswa menjelaskan konsep-konsep yang sudah diberikan yakni dalam penelitian ini, setelah mereka mendiskusikan hasil percobaan mereka yang berkaitan dengan konsep-konsep yang sudah diberikan. Dengan demikian, analisis pemikiran melalui kegiatan percobaan mempermudah mencapai konsep. Konsepkonsep yang diutamakan adalah konsep-konsep paling inklusif. Konsep-konsep tersebut sudah "diketahui" dan terdapat dalam struktur kognitif siswa yang bersifat hipotesis. Apabila materi baru berkonflik dengan struktur kognitif yang ada atau tidak begitu terkait maka tidak ada kaitan yang tersedia, informasi atau gagasan mungkin tidak dapat digabungkan. Agar tidak berlangsung, harus diurutkan materi yang dipelajari dan menyajikannya dengan cara sedemikian rupa sehingga landasan ideasional tersedia. Selain itu, siswa harus aktif mecerminkan materi-materi baru yang dimana harus berpikir melalui kaitan-kaitan yang menyesuaikan perbedaan atau ketidakcocokan dan mencatat kesamaan dengan informasi yang sudah ada.

Peta konsep dan model pembelajaran advance organizer mempunyai kaitan erat dengan pembelajaran bermakna. Pembelajaran bermakna (meaningful) merupakan suatu proses menghubungkan informasi baru pada konsep-konsep relevan yang terdapat dalam struktur kognitif siswa. Penghubung informasi baru dengan yang sudah diketahui diperlukan advance organizer yakni dalam penelitian digunakan sebagai model pembelajaran. Selain itu, peta konsep diperlukan sebagai pengorganisasian konsep-konsep yang akan membantu siswa tersebut memahami konsepkonsep pembelajaran yang di ajarkan sehingga struktur kognitif siswa terbentuk, karena semakin konsep-konsep terorganisir dengan baik maka siswa akan semakin belajar sepenuhnya.

Menciptakan belajar bermakna, konsep baru atau informasi baru dikaitkan kembali terhadap konsep-konsep yang sudah ada dalam struktur kognitif siswa itu sendiri yang dapat dilakukan dengan memberikan bantuan berupa peta konsep. Peta konsep dapat menyatakan hubungan bermakna antara konsep-konsep dalam bentuk proposisi. Hasil penelitian ini diperkuat oleh Harjono (2011) bahwa advance organizer dapat membantu agar informasi lebih bermakna (meaningful) dengan menghubungkan pengetahuan sebelumnya dengan pengetahuan baru dan berfungsi sebagai intellectual scaffolding. Selain itu, penelitian dari Yogihati (2010) bahwa penggunaan peta konsep dalam pembelajaran akan menciptakan suasana pembelajaran yang bermakna. Penelitian Aziz \& Jair (2009) mengatakan bahwa pelajar dapat menerima penggunaan peta konsep sebagai teknik pengajaran karena mudah mengingat fakta, menarik, dan tidak membosankan.

Berdasarkan kajian teoritis dan temuantemuan penelitian di atas dapat dinyatakan bahwa advance organizer berbantuan peta konsep dapat membantu untuk mengembangkan pengetahuan siswa secara mendalam karena siswa belajar dengan mengalami dan mengamati sendiri suatu proses atau kejadian serta membantu siswa dalam mengembangkan pengetahuannya sendiri. Model pembelajaran advance organizer berbantuan peta konsep ialah model pembelajaran yang menuntut siswa untuk aktif dalam menemukan kebenaran akan konsepkonsep yang dipelajarinya melalui suatu kegiatan eksperimen. Selain itu, model pembelajaran advance organizer berisi konsep atau gagasan yang dapat dihubungkan dengan konsep-konsep atau materi-materi fisika yang dipelajari sehingga siswa lebih memahami konsep-konsep atau materi-materi fisika dibandingkan dengan menggunakan model pembelajaran langsung (direct instruction). Sebelum disajikan materi baru secara efektif, siswa harus dipastikan sudah jelas dengan materi sebelumnya agar kejelasan struktur kognisi siwa terjaga. Memperkuat struktur kognitif siswa dengan cara ini mempermudah perolehan dan daya ingat informasi baru bagi siswa. Penyusun yang paling utama pada model pembelajaran advance organizer adalah penggunaan konsep-konsep, istilah, dan proposisi yang sudah dikenal siswa seperti halnya dengan contoh-contoh yang di berikan berdekatan dengan kehidupan sehari-hari siswa. Fase pertama, dalam langkah-langkah 
pembelajaran advance organizer ini disajikan peta konsep sebagai advance organizer atau penghubung siswa selama proses pembelajaran. Fase kedua, ini siswa disajikan materi dan siswa melakukan percobaan-percobaan dari materi yang sudah dijelaskan. Fase ketiga ini struktur kognitif siswa di perkuat dengan cara setelah mendiskusikan bersama kelompoknya, siswasiswa harus mempresentasikan hasil diskusi mereka sehingga bisa diketahui terjadi miskonsepsi atau tidak dengan yang sudah diterangkan dengan yang dipraktikan, serta menyimpulkan bersama akhir dari materi yang diterangkan dengan yang dipraktikan agar lebih memudahkan siswa untuk mengkaitkan materi selanjutnya.

Proses pembelajaran juga dilakukan percobaan-percobaan yang membantu siswa untuk aktif dalam kegiatan pembelajaran. Hal tersebut tentunya menjadi daya tarik tersendiri bagi siswa yang selama ini jarang melakukan praktikum IPA, khususnya praktikum fisika. Penelitian ini sama dengan penelitianpenelitian sebelumnya yang menunjukkan advance organizer sangat mempengaruhi siswa untuk menghubungkan konsep dan membedakan materi lama dengan materi baru. Apalagi penggunan peta konsep yang membantu mengorganisir konsep-konsep dengan baik, sehingga advance organizer yang dijadikan model pembelajaran dengan bantuan peta konsep mampu meningkatkan kognisi siswa. Selain itu, dapat dilihat dari hasil tes akhirnya yang cenderung lebih meningkat dibandingkan dengan tes awalnya.

Perhitungan $N$-gain pada kedua kelas yang bertujuan untuk membandingkan peningkatan hasil tes awal dengan tes akhir, diantara kelas eksperimen dan kelas kontrol pada setiap sub materi. Hasil yang didapatkan menunjukkan peningkatan pada kelas eksperimen lebih tinggi daripada kelas kontrol. Hal ini dapat dilihat pada perhitungan skor $N$ gain siswa secara keseluruhan. Kemudian, skor $\mathrm{N}$-gain per sub materi kelas eksperimen mengalami peningkatan lebih tinggi dari kelas kontrol pada sub materi: konsep tekanan, tegangan permukaan, gejala kapilaritas dan viskositas. Skor $N$-gain untuk sub materi konsep hukum Pascal, hukum Hidrostatika, dan hukum Archimedes pada kelas eksperimen lebih rendah dibandingkan dengan kelas kontrol. Hasil tersebut disebabkan karena pemberian materi bertumpuk yang menyebabkan peta konsep yang diberikan pada kelas eksperimen lebih rumit. Selain itu, proses penyampaian yang tidak efektif pada saat pembelajaran juga mempengaruhi skor $N$-gain pada kelas eksperimen dan siswa cenderung tidak bisa membedakan ketiga hukum tersebut. Namun, hasil paling rendah pada kedua kelas pada konsep hukum Archimedes, walaupun kelas kontrol lebih unggul dibandingkan kelas eksperimen yakni dengan 39\% dan 34\%. Perbedaan Antara kedua kelas masih dikatakan wajar, tapi bisa dikatakan siswa-siswa di kedua kelas cenderung tidak memahami konsep yang sudah di ajarkan. Selain itu, disebabkan penyebaran soal konsep hukum Archimedes lebih banyak dibandingkan dengan konsep hukum Hidrostatika dan hukum Pascal, sehingga persentase hukum Archimedes lebih sedikit dibandingkan konsep kedua hukum tersebut. Sehingga, diperlukan penyebaran soal yang efektif dan merata pada setiap sub materi, agar tidak terjadi penyimpangan hasil.

Perbedaan skor $\mathrm{N}$-gain pada sub materi viskositas juga mengalami perbedaan yang sedikit yaitu $1 \%$ ini disebabkan materi yang ajarkan tidak di atur baik dalam pelaksanaan pembelajaran yang seharusnya peta konsep dibedakan dengan tegangan permukaan dan gejala kapilaritas, agar terlihat perbedaan pada sub materi ini. Skor $\mathrm{N}$-gain pada sub materi tekanan, tegangan permukaan, dan gejala kapilaritas terlihat mengalami perbedaaan yang dikatakan wajar disebabkan materi yang disampaikan sesuai dengan peta konsep yang sudah disediakan dan penyampaian materi yang efektif. Selain itu, perbedaan skor $N$-gain tidak wajar ini disebabkan sebaran atau pemerataan jumlah soal yang tidak wajar pada tiap sub materi. Hasil penelitian diperkuat oleh Dahar (2011) yang menyatakan pengetahuan guru tentang perkembangan kognitif dan perkembangan bahasa akan menyediakan informasi tambahan, bukan hanya untuk menentukan konsep yang diajarkan, melainkan juga untuk menentukan tingkat-tingkat yang dapat kita harapkan dicapai oleh para siswa. 
Data hasil belajar fisika siswa pada ranah afektif terdapat perbedaan antara kelas eksperimen dan kelas kontrol selama proses pembelajaran. Proses pembelajaran pada ranah afektif menekankan pada bagaimana kepribadian siswa bersikap dan bertingkah laku serta menghargai orang lain selama proses pembelajaran. Berdasarkan hasil pengamatan selama kegiatan pembelajaran bahwa hasil belajar fisika pada ranah afektif, siswa pada kelas eksperimen lebih baik daripada kelas kontrol. Pembelajaran menggunakan model pembelajaran advance organizer berbantuan peta konsep lebih baik dan efektif untuk menumbuhkan sikap ilmiah siswa. Siswa menjadi termotivasi ketika belajar menemukan sesuatu dari pada mendengarkan apa yang di jelaskan oleh gurunya. Kelas eksperimen dan kelas kontrol meskipun sama-sama meningkat di setiap pertemuannya, tetapi kelas eksperimen lebih besar meningkatnya dibandingkan kelas kontrol. Berdasarkan uji hipotesis hasil belajar pada ranah afektif berpengaruh terhadap hasil belajar fisika siswa SMAN 1 Lingsar. Hal ini terlihat bahwa thitung $>t_{\text {tabel }}$ yaitu 3,02 $>2,00$ sehingga dapat disimpulkan bahwa terdapat pengaruh model pembelajaran advance organizer berbantuan peta konsep terhadap hasil belajar fisika siswa pada ranah afektif SMA Negeri 1 Lingsar.

Data hasil belajar fisika siswa pada ranah psikomotor juga terdapat perbedaan antara kelompok kelas eksperimen dan kelas kontrol selama proses pembelajaran. Hal ini terjadi karena selama pembelajaran siswa melakukan praktikum setiap pertemuan yaitu sebanyak tiga kali. Setiap praktikum yang dilaksanakan, siswa dituntut untuk mengisi lembar kerja siswa (LKS) secara berkelompok. Hasil belajar pada ranah psikomotor lebih menekankan pada pemberian pengalaman kepada siswa untuk terampil mengerjakan sesuatu dengan menggunakan keadaan yang dimiliki. Dengan demikian, dalam melakukan percobaan secara tidak langsung melatih keterampilan siswa menjadi lebih baik.

Hasil pengamatan yang dilakukan menunjukkan bahwa keterampilan siswa selama kegiatan pembelajaran meningkat dengan baik pada setiap pertemuan. Hasil dalam penelitian ini juga semakin menguatkan teori bahwa melalui pembelajaran advance organizer berbantuan peta konsep siswa tidak hanya memahami konsep yang relevan dengan masalah yang menjadi pusat perhatian, tetapi juga memperoleh pengalaman belajar yang berhubungan dengan keterampilan menerapkan metode ilmiah. Hasil belajar dalam ranah kognitif dengan bantuan peta konsep sebagai alat penghubung konsep-konsep yang dipelajari, menyebabkan pembelajaran menjadi lebih menarik dan pengetahuan awal dengan pengetahuan baru siswa terhubung, sehingga membangkitkan siswa ingin belajar dan mudah mengenali konsep-konsep yang dipelajarinya. Antusias siswa dalam belajar ini akan mempengaruhi pada ranah afektif dan psikomotor, disebabkan perhatian siswa lebih fokus mengikuti setiap tahap pembelajaran, ini menunjukkan tiga ranah ini saling berhubungan dalam meningkatkan hasil belajar fisika siswa di SMA Negeri 1 Lingsar.

\section{PENUTUP}

Berdasarkan hasil dan pembahasan yang telah dipaparkan, maka dapat disimpulkan bahwa model pembelajaran advance organizer berbantuan peta konsep berpengaruh positif terhadap hasil belajar fisika siswa SMA Negeri 1 Lingsar. Adapun saran yang dapat diberikan yaitu pembelajaran advance organizer berbantuan peta konsep dapat diterapkan oleh guru dalam proses belajar mengajar di kelas dan menambah variasi model pembelajaran yang akan digunakan. Dengan memperhatikan alokasi waktu, alat dan bahan yang digunakan dalam pembelajaran serta peta konsep yang akan digunakan.

\section{REFERENSI}

Aziz, A., Rokhmat, J., \& Kosim. 2015. Pengaruh Model Pembelajaran Berbasis Masalah Dengan Metode Eksperimen Terhadap Hasil Belajar Fisika Siswa Kelas X SMAN 1 Gunungsari Kabupaten Lombok Barat Tahun Pelajaran 2014/2015. Jurnal Pendidikan Fisika dan Teknologi. 1(3), 200-204.

Aziz, Z. dan Jair, N. 2009. Penggunaan Peta Konsep Untuk Meningkatkan Pencapaian 
Mata Pelajaran Sejarah Bagi Pelajar Tingkatan Dua, Jurnal Pendidikan Malaysia. 34(1), 3-15.

Dahar, R. W. 2011. Teori - Teori Belajar dan Pembelajaran. Bandung: Erlangga.

Fadila, I., Siswandiri, \& Ivada, E. 2015. Penerapan Advance Organizer Meningkatkan Keaktifan Dan Hasil Belajar Akuntasi. Jurnal "Tata Arta". 1(2), 237-248.

Harjono, A. 2011. Perbedaan Strategi Pembelajaran dan Pemberian Advance Organizer Pengaruhnya Terhadap Hasil Belajar Fisika Siswa Kelas X. Jurnal Pijar Matematika Ilmu Pengetahuan Alam. 7(1), 13-17.

Joyce, B., Weil, M., \& Calhaun, E. 2016. Models of Teaching. Yogyakarta: Pustaka Pelajar.

Nurhayati, S., \& Subroto. 2012. Peningkatan Hasil Belajar Mahasiswa Pada Mata Kuliah Kimia Dasar II Dengan Menggunakan Peta Konsep Berorientasi Chemoentrepreneurship (CEP). Jurnal Penelitian Pendidikan. 29(1), 34-42.

Nurqomariah, Gunawan, \& Sutrio. 2015. Pengaruh Model Problem Based Learning Dengan Metode Eksperimen Terhadap Hasil Belajar IPA Fisika Siswa Kelas VII SMP Negeri 19 Mataram Tahun Pelajaran 2014/2015. Jurnal Pendidikan Fisika dan Teknologi. 1(3), 173-178.

Oloyede, O. I. 2011. A Meta - Analysis Of Effects Of The Advance Organizers On Acknowledgment And Retention Of Senior Secondary School (SSS) Chemistry. Jurnal Education. 3(2), 129135.

Pahriah. 2016. Teori Belajar Dan Aplikasinya Dalam Pembelajaran. Selong: CV. Garuda Ilmu.

Rahayu, S., Widodo, A.T., \& Supartono. 2010. Pengembangan Model Pembelajaran Advance Organizer Untuk Meningkatkan
Aktivitas dan Hasil Belajar Siswa. Jurnal Inovasi Pendidikan Kimia. 4(1), 497-505.

Sinulangga \& Munte, D. 2013. Pengaruh Model Pembelajaran Advance Organizer Berbasis Mind Map Terhadap Hasil belajar Fisika Siswa Pada Materi Pokok Besaran Dan Satuan Di Kelas X SMA. Jurnal Pendidikan Fisika. 1(2), 1-6.

Susanti, F., Ayub, S., \& Taufik, M. 2016. Perbedaan Hasil Belajar Fisika Melalui Model Pembelajaran Kooperatif Tipe Numbered Heads Together (NHT) Berbantuan Kartu Soal dengan Model Pembelajaran Direct Instruction Di SMAN 7 Mataram. Jurnal Pendidikan Fisika dan Teknologi. 2(4), 147-153.

Yogihati, C. I. 2010. Peningkatan Kualitas Pembelajaran Fisika Umum Melalui Pembelajaran Bermakna dengan Menggunakan Peta Konsep. Jurnal Pendidikan Fisika Indonesia. 6, 104-107.

Widodo \& Widayanti, L. 2013. Peningkatan Aktivitas Belajar dan Hasil Belajar Siswa dengan Metode Problem Based Learning pada Siswa Kelas VIIa MTS Negeri Donomulyo Kulon Progo Tahun Pelajaran 2012/2013. Jurnal Fisika Indonesia. 17(49), 32-35. 